\title{
Novel electrodialysis-electrochlorination integrated process for the reclamation of treated wastewaters
}

\author{
J. Llanos*, S. Cotillas, P. Cañizares, M. A. Rodrigo. \\ Department of Chemical Engineering. Faculty of Chemical Sciences and Technologies. \\ University of Castilla-La Mancha. Avda. Camilo José Cela, 12. 13071 Ciudad Real. \\ Spain.
}

\begin{abstract}
This work presents a novel integrated process for the reclamation of wastewaters. This process combines, in the same cell, the reduction in the effluent conductivity and TOC by electrodialysis together with the production of a value added stream, which can be used for disinfection purposes. In the diluate compartment, the solution is desalted whereas hypochlorite is electrochemically synthesized in the anolyte. The treatment of actual effluents from the Waste Water Treatment Plant (WWTP) of Ciudad Real (Spain) was confronted. It was observed that the concentration of hypochlorite synthesized in the anolyte increased when anolyte and catholyte are separated into different circuits, avoiding the reduction of hypochlorite on the cathode surface. Furthermore, a higher voltage to cell pair ratio also enhances the production of hypochlorite. Finally, it was checked the disinfectant potential of the final anolyte, being possible to produce a desalted and disinfected final stream with a total electrical consumption of $1.03 \mathrm{~W} \mathrm{~h} \mathrm{dm}{ }^{-3}$ and dosing a volumetric ratio anolyte:diluate of 4:96.
\end{abstract}

Keywords: Electrodialysis, electrochlorination, TOC removal, wastewater reclamation, integrated process.

*To whom all correspondence should be addressed.

Tel. +34 902204100 ext 3508

Fax. +34926295256.

e-mail: javier.llanos@uclm.es 


\section{Introduction}

Reclaimed wastewaters are a water resource that has not been extensively used so far. Focussing on Spain, a country with a great demand of water sources (overall water demand of around $22,000 \mathrm{hm}^{3}$ year $\left.^{-1}[1]\right)$ and a pioneering regulation, the total volume of regenerated water means only around $2 \%$ of its total water demand [2]. In a process of wastewater reclamation, a wastewater effluent, which has been previously treated by a conventional treatment, is further purified in order to fit the requirements for different uses (irrigation, recreational, environmental, etc.). Some advantages of the use of this type of water resource are the reduction of the overall net water demand, the decrease in industrial production costs due to the use of high quality regenerated water and the decrease in the loss of water to the sea.

Within the last years, electrochemical technologies have experienced great advances in the treatment of wastewaters due to the development of new electrode materials and novel electrochemical processes [3-8]. One of the electrochemical technologies most widely used in the industry is electrodialysis. This technique consists of an unitary process that uses semi-permeable membranes to separate or concentrate dissolved ions. The depleted solution is generally referred to as the diluate and the concentrated solution as the brine or the concentrate [9]. Electrodialysis is a process currently used in brackish water desalination and potable water production [10-12]. Recently, different applications of electrodialysis in food, medicine and chemistry industries, as well as biotechnology and wastewater treatment, have been proposed [13-16]. Another electrochemical process applied in the treatment of wastewater is electrodisinfection, which consists of an 
electrolytic production of oxidizing species either from the ions initially contained in the target wastewater or from reagent dosed (e. g. sodium chloride) [17-20].

One of the drawbacks of electrochemical technologies is the high cost, which depends on the energy consumption (operating), and on the high price of the electrode material (investment). For this reason, a hot topic in this research subject is to explore alternatives to diminish these operating and investment costs and hence, to develop electrochemical processes more cost-effective and energy-efficient. In this context, process integration emerges as a good alternative in electrochemical process. This process integration represents the union, in one single stage, of basic operations that are traditionally carried out separately. Regarding wastewater treatment, many authors have proposed combined electrochemical processes to minimize the operation costs. Thus, Jüttner et al. [21] reviewed different integrated industrial processes such as the treatment of highly concentrated salt solutions together with the production of acids and bases [22] or the combination of ion exchange membranes and conventional ion exchange resins for the treatment of water and process solutions with continuous regeneration of the ion exchanger [23]. Another example is the work of Rockstraw et al. [24], who proposed an integrated electrodialysis-evaporation process for the treatment of aqueous streams. Linares-Hernández et al. [25] described a combined electrocoagulation-electrooxidation treatment for industrial wastewater and Durante et al. [26] proposed a combination of electrocoagulation and advanced oxidation processes for removal of Cr-EDTA from wastewaters. However, these last works consist of combining different techniques in successive steps but not within the same experimental set-up. In contrast, Mahvi et al. [27] proposed an electrocoagulation/electrooxidation-electroflotation reactor for the simultaneous removal of ammonia and phosphate from wastewater. In that work, the 
electrochemical cell consisted of one reactor with two different units: one electrochemical and one more for separation using aluminium, stainless steel and $\mathrm{RuO}_{2} / \mathrm{Ti}$ as electrodes. More recently, Cotillas et al. demonstrated the viability of an electrocoagulation/electrodisinfection cell using Al bipolar electrodes [28] to carry out simultaneous disinfection and removal of turbidity.

Within this context, the present work is focused on the assessment of the performance of a novel integrated electrodialysis-electrochlorination (ED-ECh) integrated cell for the treatment of actual wastewaters from the WWTF of Ciudad Real (Spain). The proposed process is schematized in Figure 1. The actual effluent from a Waste Water Treatment Facility (WWTF) is conducted through an electrodialysis/electrochlorination integrated cell. In this cell, a portion of the initial effluent is desalted (diluate) meanwhile the rest is concentrated (concentrate). In addition, the electrode-rinsing solution of the electrodialysis cell is fed with a $\mathrm{NaCl}$ solution in order to obtain a value-added hypochlorite stream, which can be used as disinfectant. Thus, the final streams of this process are: 1) a concentrated stream which should be discharged to the environment; 2) a valorized stream, desalted and disinfected, ready to be reclaimed. In this work, the effect of three key parameters (cell configuration, number of cell pairs and concentration of $\mathrm{NaCl}$ in the electrode rinsing solution) on the performance of the ED-ECh cell is studied. Furthermore, disinfection tests with the final electrode rinsing solution were carried out to evaluate the actual disinfection potential of this stream. 


\section{Experimental}

\subsection{Electrodialysis-electrochlorination cell.}

The experimental set up, schematized in Fig. 2, was provided by PCCell (Germany). Cationic (Neosepta CMX) and anionic (Neosepta AMX) standard ion exchange membranes from ASTOM CORP were used. The surface area per membrane was $69 \mathrm{~cm}^{2}$. Depending on the number of membranes placed inside the stack, it was composed of a different number of cell pairs (diluate+concentrate), being 3 cell pairs for 7 membranes ( 3 anionic, 4 cationic) and 6 cell pairs for 13 membranes ( 6 anionic, 7 cationic). With this configuration, the concentration of both catholyte and anolyte was maintained constant throughout the tests, closing the ionic circuit and behaving as "electrode rinsing" solutions. In all cases, the ion exchange membranes in contact with both anolyte and catholyte, were cationic exchange membranes, in order to avoid the migration of the synthesised hypochlorite.

Dimensionally stable anodes (DSA) were used as electrodes. DSA anodes were supplied by PcCell and made of titanium coated with mixed metal oxides $\left(\mathrm{IrO}_{2}-\mathrm{RuO}_{2}\right)$. DSA electrodes (anode and cathode) were square in shape $\left(56.25 \mathrm{~cm}^{2}\right)$. Wastewater was stored in glass tanks and circulated through the electrodialysis cell by means of a centrifugal pump.

The flow rate for electrode rinsing solution was $100 \mathrm{dm}^{3} \mathrm{~h}^{-1}$ and for concentrate and diluate was $30 \mathrm{dm}^{3} \mathrm{~h}^{-1}$. Regarding the ratio between diluate and concentrate volumes, a value of 1:1 (same volume of diluate and concentrate compartments, 1.5 L) was selected. 
It is worth noting that a low diluate/concentrate ratio will lead to a strongly desalted solution in the diluate compartment with a limited increase in the concentration of the concentrate. On the contrary, a high diluate/concentrate volumetric ratio will produce a moderate increase in the concentration of the concentrate. In the present work, the main aim is not the production of a totally desalted diluate nor a highly concentrated final stream, which should be further treated prior to its disposal. For these reasons, in this first approach of the design of the ED-ECh process, a ratio 1:1 was selected.

\subsection{Experimental procedures.}

The experimental set up is designed to work with a maximum number of four different circuits (four independent tanks, pumps and tubing). In all cases, concentrate and diluate streams consist of actual effluents from the WWTF of Ciudad Real (Spain), meanwhile streams that are in contact with electrodes were $\mathrm{NaCl}$ solutions.

Depending on the number of different circuits used, the cell was operated at two different configurations:

1) Four compartments configuration (4C). In this configuration, diluate, concentrate, catholyte and anolyte were circulated through four independent circuits, thus giving four different solutions.

2) Three compartments configuration (3C). In this case, catholyte and anolyte are mixed, so the cell worked with three independent circuits, one for the diluate, one for the concentrate and one for a mixture of anolyte and catholyte (electroderinsing). 
Bench scale ED-ECh tests were carried out under potentiostatic conditions (voltage is constant) and at discontinuous mode of operation to determine the influence of the main parameters in the process. The temperature of the system is kept constant by means of a thermosttated bath and a heat exchanger at $25^{\circ} \mathrm{C}$. The $\mathrm{pH}$ of anolyte (for $4 \mathrm{C}$ scheme) or electrode-rinsing solution (for $3 \mathrm{C}$ scheme) was maintained constant at a value of 11 by the addition of $\mathrm{NaOH}\left(1 \mathrm{~mol} \mathrm{dm}{ }^{-3}\right)$, in order to promote the formation of hypochlorite.

\subsection{Analytical procedures.}

The anions present in the target wastewater were characterized using ion chromatography by means of a Shimadzu LC-20A system. A Shodex IC I-524A column was used for the anionic separation and it was packed with an ion exchange resin that was formulated by bonding a quaternary ammonium group to a hydrophilic gel. The peaks were identified and quantified using LCsolution Chromatography Workstation, version 1.23. In the case of hypochlorite, the peak of chromatogram interferes with the chloride peak. Therefore, the determination was realized by titration with $\mathrm{As}_{2} \mathrm{O}_{3}$ in $\mathrm{NaOH} 2 \mathrm{M}$ [20]. The same ion chromatography equipment (column, Shodex IC YK-421) was used to measure the nitrogen inorganic cation $\left(\mathrm{NH}_{4}^{+}\right)$.

Total calcium, magnesium, potassium and sodium concentrations were measured off-line using an inductively coupled plasma spectrometer (Liberty Sequential, Varian) according to a standard method [29] (plasma emission spectroscopy). In order to evaluate the total metal concentrations, samples were diluted to $50: 50 \mathrm{v} / \mathrm{v}$ using $4 \mathrm{~N} \mathrm{HNO}_{3}$ so as to ensure the total solubility of the metal. 
The faecal coliforms of the wastewaters were estimated using the most probable number (MPN) technique. The microorganism counts were carried out by the multiple-tubefermentation technique $\left(24 \mathrm{~h}\right.$ of incubation at $\left.44{ }^{\circ} \mathrm{C}\right)$ using five tubes in each dilution $(1: 10,1: 100$, and 1:1000).

\subsection{Composition of the actual effluents.}

The samples of the actual effluent treated wastewater were taken from the outlet of the secondary clarifier of the WWTF of Ciudad Real (Spain). In order to assure a good conservation of the effluent, the experiments were carried out just after the collection of the samples. Although the composition of the effluent can vary depending on the collection date, Table 1 shows a representative average composition of the target effluent to be treated.

\section{Results and discussion}

The first step of the work consisted in testing and optimizing the performance of the integrated ED-ECh cell. In this first part of the work, the influence of the cell configuration, number of cell-pairs and anion concentration on the process performance was evaluated. Next, the disinfectant potential of the anolyte produced was tested by carrying out disinfection tests using increasing dosing of this stream. 


\subsection{Optimization of the ED-ECh cell performance.}

\subsubsection{Selection of the optimal cell configuration.}

The first step to optimize the process consisted on the selection of best configuration of the ED-ECh cell. At this point, two different cell configurations (three compartments and four compartments) were tested.

First of all, an ED-Ch test was carried out at a constant total voltage of $7 \mathrm{~V}$, with a $\mathrm{NaCl}$ concentration of $1500 \mathrm{mg} \mathrm{dm}^{-3}$ in the electrode-rinsing solution, with three cell pairs and using a three-compartments scheme (3C, catholyte and anolyte together). Results are shown in Fig. 3.a (evolution of conductivity, $\sigma$, in diluate compartment and current efficiency) and Fig. 3.b (evolution of $\mathrm{ClO}^{-}$concentration in the electrode rinsing compartment). In respect of the current efficiency, this parameter has been calculated as the ratio of the electrical charge that is used to transport ions from the diluate to the concentrate compartment. The total charge applied is calculated by Eq. 1, taking into account that the cell was operated at constant voltage (and not at constant current density)

$$
\mathrm{Q}=\int \mathrm{I} \cdot \mathrm{dt}
$$

Where $\mathrm{Q}$ is the applied electrical charge (C), I is the recorded intensity (A) and $t$ is the time (s).

As it can be observed, conductivity in diluate compartment can be reduced below $100 \mathrm{mS}$ $\mathrm{cm}^{-1}$. The initial current efficiency was $52 \%$, meanwhile this value decreased with the applied electric charge, reaching a final value of $16 \%$, values that are in accordance with 
typical current efficiencies reported for electrodialysis systems [30]. The decrease in the current efficiency is also common of electrodialysis systems [31] and is explained by the increase in the diffusion of ions from the concentrate compartment, due to the increasing concentration gradient. With respect to the concentration of hypochlorite, it initially increased and it finally descended to zero, reaching a maximum of $4.06 \mathrm{mg} \mathrm{l}^{-1}$ for an applied electrical charge of $0.028 \mathrm{~A} \mathrm{~h} \mathrm{dm}^{-3}$. Both chlorate and perchlorate were not detected in the system.

Another important parameter to be monitored is the Total Organic Carbon (TOC) in the diluate chamber. Fig. 4 represents the evolution of this parameter with respect to the applied electrical charge. As it can be observed, TOC concentration in diluate compartment decreases with the applied electrical charge. In a simple approach, the dissolved organic matter in a natural water source or an effluent from a WWTP can be classified into a hydrophobic (mainly humic acids and fulvic acids), a transphilic and a hydrophilic fraction $[32,33]$. A high proportion of the hydrophobic fraction in the target effluent may represent a major operative drawback for electrodialysis processes due to the adsorption of these organic molecules on the membrane surfaces, causing fouling [34]. On the contrary, low molecular weight hydrophilic acids can permeate through electrodialysis membranes depending on the type of membrane and the conditions of $\mathrm{pH}$ and ionic strength [35]. Taking into account this, the target effluent of the present work may be formed mainly by low molecular weight hydrophilic organic matter that can permeate through the selected membranes. This composition (mainly hydrophilic fraction) has also been reported in other works of characterization of the soluble organic matter of effluents from WWTPs [36]. At this point, it is important to remark that 
reducing the soluble organic matter of the target effluent will also limit the formation of disinfection chlorinated by-products that are harmful to human health.

Next, the cell was operated with a four compartments configuration that is, separating catholyte and anolyte in two different circuits. The rest of experimental conditions were maintained as in the previous test. Results regarding time course of diluate conductivity, current efficiency (Fig. 5.a) and hypoclorite concentration (Fig. 5. b) are gathered in Fig. 5.

As it can be observed, the performance of the electrodialysis process is similar to that obtained for the three-compartments configuration that is, similar profile of the diluate concentration and current efficiency. On the contrary, the maximum concentration of synthesized hypochlorite is $11.6 \mathrm{mg} \mathrm{dm}^{-3}$, almost three-fold the maximum value obtained with the three-compartments configuration. In addition, this concentration is maintained constant when increasing the electrical charge passed through the cell.

To explain the lower efficiency of the $3 \mathrm{C}$ scheme for the synthesis of hypochlorite, it is necessary to take in mind the possible reduction reactions that this compound can suffer in an undivided electrochemical cell. Chemistry of chlorine in aqueous solution and, specifically, reactions involving hypochlorite (Eqs. 2-4) have been extensively studied in the production of chlorate $[37,38]$, as the reduction of hypochlorite results in a loss of efficiency of the process.

$$
\begin{aligned}
& 6 \mathrm{ClO}-+3 \mathrm{H}_{2} \mathrm{O} \leftrightarrow 2 \mathrm{ClO}_{3}^{-}+4 \mathrm{Cl}^{-}+6 \mathrm{H}^{+}+3 / 2 \mathrm{O}_{2}+6 \mathrm{e}^{-} \\
& \mathrm{ClO}^{-}+\mathrm{H}_{2} \mathrm{O}+2 \mathrm{e}^{-} \leftrightarrow \mathrm{Cl}^{-}+2 \mathrm{OH}^{-}
\end{aligned}
$$




$$
2 \mathrm{HClO}+\mathrm{ClO}^{-} \leftrightarrow \mathrm{ClO}_{3}{ }^{-}+2 \mathrm{Cl}^{-}+2 \mathrm{H}^{+}
$$

Reaction (2) takes place on the anode, reaction (3) on the cathode and reaction (4) in the bulk solution. In the present study, the concurrence of reactions (2) and (4) should be discarded because chlorate and perchlorate ions were not detected under the conditions tested in the present work. Thus, hypochlorite reduction to chloride may be the responsible of the lower concentration of hypochlorite that is measured when catholyte and anolyte are not separated into different circuits.

According to these results, a 4C configuration was selected to carry on with the optimization of the ED-ECh cell. With this scheme, it is possible to produce higher concentrations of hypochlorite in the electrode rinse solution, meanwhile the efficiency of the electrodialysis process remains unaltered with respect to the $3 \mathrm{C}$ configuration.

\subsubsection{Optimizacion of the number of cell pairs.}

The next step in the optimization process of the ED-ECh cell consisted on modifying the number of cell pairs, working at a constant voltage of $7 \mathrm{~V}$ and with a $4 \mathrm{C}$ scheme. The main aim of this part of the work is studying the influence of the ratio of the applied voltage to the number el cell pairs. Fig. 6 shows the results regarding the evolution with time of diluate conductivity (6.a) and hypochlorite concentration in the anolyte (6.b), for a test carried out with 6 cell pairs.

If these results are compared with those gathered in Fig. 4 (carried out with 3 cell-pairs), it is easy to deduce that a higher voltage per cell pair (a lower number of cell pairs) decreases the rate of the electrodialysis process but enhances the rate of hypochlorite 
generation. The higher rate of the electrodialysis process is simply explained by the higher number of cell pairs and, thus, the higher capacity of the cell to transport ion from the diluate compartment.

To explain the higher rate of hypochlorite generation, it is necessary to note that the total potential in an electrodialysis cell can be obtained as the sum of the equilibrium potencial of the electrodes, their overpotential and the voltage drop due to the resistance of membranes, electrolyte and external circuit [10]. Taking this in mind, it is easy to note that the resistance of the cell will be lower when working with a lower number of cell pairs. Consequently, the available potential to perform the reactions in the electrode surface will be higher when working with 3 cell pairs and, thus, the intensity that flows through the cell is expected to be higher in this case (intensity results are included as supplementary material).

Thus, working with a higher ratio of applied voltage to number of cell pairs enhances the rate of hypochlorite generation but lowers the performance of the electrodialysis. At this point, it is important to take in mind that the aim of this work is the optimization of the integrated ED-ECh cell. Thus, the next test of this work will be carried out with a total applied voltage of $7 \mathrm{~V}$ and a number of three cell pairs, in order to maximize the production of oxidants in the anolyte and, consequently, maximize the added value of the proposed process. 


\subsubsection{Optimization of the anolyte concentration.}

Once the cell configuration and the number of cell pairs have been selected for the EDECh integrated cell, the next variable to be optimized was the $\mathrm{NaCl}$ concentration that is used in the anolyte. Thus, Fig. 7 shows the evolution of the synthesized hypoclorite in the anolyte for increasing $\mathrm{NaCl}$ concentrations, working with a $4 \mathrm{C}$ cell configuration, $7 \mathrm{~V}$ of total voltage and 3 cell pairs.

As it can be observed, both the initial rate of hypochlorite synthesis and the maximum concentration of this oxidant increases for increasing $\mathrm{NaCl}$ concentrations until $750 \mathrm{mg}$ $\mathrm{dm}^{-3}$, till the profile of hypochlorite synthesis becomes independent of the $\mathrm{NaCl}$ concentration. The initial increase in the rate of the formation of hypochlorite can be related to a higher conductivity in the anolyte (lower resistance and higher intensity) and a lower contribution of mass transfer limitations due to the higher concentration of chloride. From $750 \mathrm{mg} \mathrm{dm}^{-3}$, the system seems not to be influenced by the value of the chloride concentration thus working at the maximum rate of hypochlorite generation under the selected working conditions.

As the anolyte is aimed to be used for the disinfection of the diluate stream, it is important that the conductivity of the anolyte was the lowest, in order not to increase the conductivity of the final product. Taking into account this, an anolyte concentration of $750 \mathrm{mg} \mathrm{dm}^{-3}$ was selected, as this concentration is the minimum one above which the rate of hypochlorite generation is not affected by the concentration of chloride. 


\subsection{Disinfection tests of actual effluents.}

Once the working parameters of the ED-ECh cell were optimized, a final test was carried out in order to determine the optimal anolyte dosing required to disinfect the diluate stream. This test is composed of two steps. First of all, an ED-ECh test was carried out, working at the conditions previously optimized. This test was performed until the conductivity of the diluate stream reached a threshold of $100 \mu \mathrm{S} \mathrm{cm}{ }^{-1}$. This value is considered to be the maximum quality threshold (the most restrictive) that could be required for the target effluent in a hypothetical reclamation process. Next, the disinfection capacity of the final anolyte was tested by dosing increasing concentrations of this stream to the final diluate. This sequence emulates the proposed process of water reclamation and sheds light on the final quality of this reclaimed stream.

With respect of the first part of the test (ED-ECh process), the results (not shown) where similar to those previously presented, with a maximum hypochlorite concentration in the anolyte of $12 \mathrm{mg} \mathrm{dm}^{-3}$, a final diluate conductivity of $100 \mu \mathrm{S} \mathrm{cm}^{-1}$ and a final TOC concentration in the diluate of $10.5 \mathrm{mg} \mathrm{dm}^{-3}$ (from an initial concentration of $30.1 \mathrm{mg} \mathrm{dm}^{-}$

$\left.{ }^{3}\right)$. The specific electric energy consumption to reach this final conductivity was $1.03 \mathrm{~W} \mathrm{~h}$ $\mathrm{dm}^{-3}$.

Fig. 8 shows the results obtained in the second part of the test (final diluate disinfection). Fig. 8.a) shows the evolution of the concentration of E. coli for increasing doses of the anolyte, expressed as the added concentration of hypochlorite. Fig. 8.b) shows the increase in the conductivity of the diluate as a result of the dosing process. 
As it can be observed, the anolyte produced during the electrodialysis process can be successfully applied to disinfect the diluate, being necessary a volumetric ratio of 4:96 of anolyte to diluate (an added $\mathrm{ClO}^{-}$of $0.42 \mathrm{mg} \mathrm{dm}^{-3}$ ) to completely disinfect this stream. Moreover, as it can be deduced from Fig. 8.b) the increase in the conductivity of the effluent is negligible at the dosing required to disinfect the effluent. At this point, it is crucial to highlight that the presence of chlorate and perchlorate (by ion chromatography) and THMs (by gas chromatography) was discarded at the optimal dosing.

Finally, it must be remarked that the required dosing to disinfect the diluate would strongly depend on its initial E. coli concentration. Nevertheless, the low dosing required in the present study sheds light on the potential of the proposed process, with which it is possible to produce high quality reclaimed water streams. Furthermore, the non-used portion of the anolyte represents a high quality disinfection solution which can be used in any other disinfection process.

\section{Conclusions}

From this work, the following conclusions can be drawn:

- The treatment of actual wastewaters from WWTP by the proposed Ed-ECh process makes possible to reduce its conductivity and TOC concentration. Moreover, it is possible to produce a valuable hypochlorite solution in the electrode rinse compartment. 
- A configuration where catholyte and anolyte are separated in different compartments enhances the production of hypochlorite without affecting the performance of the system in terms of the reduction of both conductivity and TOC.

- Increasing the ratio of voltage to cell pairs (reduce the number of cell pairs for a given voltages) enhances the production of hypochlorite due to the lower resistance of the cell.

- It is possible to disinfect the final diluate stream by dosing reduced volumes of the anolyte (volumetric ratio anolyte:diluate 4:96), producing a value added final disinfected stream of low conductivity without unwanted harmful chlorinated by-products. The required electrical energy consumption to reach the final conductivity was $1.03 \mathrm{~W} \mathrm{~h} \mathrm{dm}-$ 3.

\section{Acknowledgements}

This work was supported by the MCT (Ministerio de Ciencia y Tecnología, Spain) through the project CTM2010-18833/TECNO and by Fundacion Iberdrola through the grants for research on energy and environmental issues. 


\section{References}

[1] Spanish National Bureau of Statistics. http://www.ine.es. Accessed September $1^{\text {st }}$, 2013.

[2] Iglesias R, Ortega E, Batanero G, Quintas L (2010) Water reuse in Spain: Data overview and costs estimation of suitable treatment trains. Desalination 263:1-10.

[3] Comninellis C, Kapalka A, Malato S, Parsons SA, Poulios I, Mantzavinos D (2008) Advanced oxidation processes for water treatment: Advances and trends for R\&D. J. Chem. Technol. Biotechnol. 83:769-776.

[4] Rodrigo MA, Cañizares P, Sánchez-Carretero A, Sáez C (2010) Use of conductivediamond electrochemical oxidation for wastewater treatment. Catal. Today 151:173177.

[5] Wang Q, Jin T, Hu Z, Zhou L, Zhou M (2012) TiO 2-NTs/SnO 2-Sb anode for efficient electrocatalytic degradation of organic pollutants: Effect of $\mathrm{TiO}_{2}-\mathrm{NTs}$ architecture. Sep. Purif. Technol. 102:180-186.

[6] Oturan N, Hamza M, Ammar S, Abdelhédi R, Oturan MA (2011) Oxidation/mineralization of 2-Nitrophenol in aqueous medium by electrochemical advanced oxidation processes using Pt/carbon-felt and BDD/carbon-felt cells. J. Electroanal. Chem. 661:66-71.

[7] Lacasa ,E Cañizares E, Llanos J, Rodrigo MA (2011) Removal of nitrates by electrolysis in non-chloride media: Effect of the anode material. Sep. Purif. Technol. 80:592-599.

[8] Kodým R, Pánek P, Šnita D, Tvrzník D, Bouzek, K (2012) Macrohomogeneous approach to a two-dimensional mathematical model of an industrial-scale electrodialysis unit. J. App. Electrochem. 42(9):645-666. 
[9] Strathmann H (2004) Ion-exchange membrane separation processes, first ed. ELSEVIER B.V., United Kingdom.

[10] Ortiz JM, Sotoca JA, Expósito E, Gallud F, García-García V, Montiel V, Aldaz A. (2005) Brackish water desalination by electrodialysis: Batch recirculation operation modeling. J. Membr. Sci. 252:65-75.

[11] Larchet C, Zabolotsky VI, Pismenskaya N, Nikonenko VV, Tskhay A, Tastanov K, Pourcelly G (2008) Comparison of different ED stack conceptions when applied for drinking water production from brackish waters. Desalination 222:489-496.

[12] Valero F, Arbós R (2010) Desalination of brackish river water using Electrodialysis Reversal (EDR) Control of the THMs formation in the Barcelona (NE Spain) area. Desalination 253:170-174.

[13] Lee JB, Park KK, Eum HM, Lee CW (2006) Desalination of a thermal power plant wastewater by membrane capacitive deionization. Desalination 196:125-134.

[14] Zhang X, Li C, Wang Y, Luo J, Xu T (2011) Recovery of acetic acid from simulated acetaldehyde wastewaters: Bipolar membrane electrodialysis processes and membrane selection. J. Membr. Sci. 379:184-190.

[15] Chindapan N, Devahastin S, Chiewchan N (2010) Effect of electrodialysis pretreatment on physicochemical properties and morphology of spray-dried-fish sauce powder. J. Food Eng. 11:491-497.

[16] Cai BX (2006) Study of membrane separation processes of a betaine-like medicinal solution. Desalination 191:432-437.

[17] Cañizares P, Sáez C, Sánchez-Carretero A, Rodrigo MA (2009) Synthesis of novel oxidants by electrochemical technology. J. Appl. Electrochem. 39:2143-2149. 
[18] Sánchez-Carretero A, Rodrigo MA, Cañizares P, Sáez C (2010) Electrochemical synthesis of ferrate in present of ultrasound using boron doped diamond anodes. Electrochem. Commun. 12:644-646.

[19] Cotillas S, Sánchez-Carretero A, Cañizares P, Sáez C, Rodrigo MA (2011) Electrochemical synthesis of peroxyacetic acid using conductive diamond electrodes. Ind. Eng. Chem. Res. 50:10889-10893.

[20] Sánchez-Carretero A, Sáez C, Cañizares P, Rodrigo MA (2011) Electrochemical production of perchlorates using conductive diamond electrolyses. Chem. Eng. J. 166:710-714.

[21] Jüttner K, Galla U, Schmieder H (2000) Electrochemical approaches to environmental problems in the process industry. Electrochim. Acta 45:2575-2594.

[22] Jörissen J, Simmrock KH (1996) Recycling of sodium sulphate by electrochemical splitting into caustic soda and sulphuric acid. Bull. Electrochem. 12:310-314.

[23] Kuppinger FF, Neubrand W, Rapp HJ, Eigenberger G (1995) Chem. Ing. Tech. 67:731.

[24] Rockstraw DA, Scamehorn JF, O’Rear III EA (1990) An integrated electrodialysisevaporation process for the treatment of aqueous process streams containing electrolytes. J. Membr. Sci. 52:43-56.

[25] Linares-Hernández I, Barrera-Díaz C, Bilyeu B, Juárez-GarcíaRojas P, CamposMedina E (2010) A combined electrocoagulation-electrooxidation treatment for industrial wastewater. J. Hazard. Mater. 175:688-694.

[26] Durante C, Cuscov M, Isse AA, Sandonà G, Gennaro A (2011) Advanced oxidation process coupled with electrocoagulation for the exhaustive abatement of Cr-EDTA. Water Res. 45:2122-2130. 
[27] Mahvi AH, Ebrahimi SJAD, Mesdaghinia A, Gharibi H, Sowlat MH (2011) Performance evaluation of a continuous bipolar electrocoagulation/electrooxidation-electroflotation (ECEO-EF) reactor designed for simultaneous removal of ammonia and phosphate from wastewater effluent. J. Hazard. Mater. 192:1267-1274.

[28] Cotillas S, Llanos J, Cañizares P, Mateo S, Rodrigo MA (2013) Optimization of an integrated electrodisinfection/ electrocoagulation process with Al bipolar electrodes for urban wastewater reclamation. Water Res. 47:1741-1750.

[29] Clesceri LS, Greenberg AE, Eaton AD (1998) Standard Methods for the Examination of Water and Wastewater, twentieth ed., American Public Health Association, Washington, DC.

[30] Sadrzadeh M, Mohammadi T (2009) Treatment of sea water using electrodialysis: Current efficiency evaluation. Desalination 249:279-285.

[31] Zhang Y, Desmidt E, Van Looveren A, Pinoy L, Meesschaert B, Van der Bruggen B (2013) Phosphate separation and recovery from wastewater by novel electrodialysis. Environ. Sci. Technol. 47:5888-5895.

[32] Thurman E. M. (1985) Organic Geochemistry of Natural Waters, 497pp. Kluwer Academic, Boston, MA, USA.

[33] Cho J, Amy G, Pellegrino J (2000) Membrane filtration of natural organic matter: factors and mechanisms affecting rejection and flux decline with charged ultrafiltration (UF) membrane. J. Membrane Sci. 164:89-110.

[34] Lee HJ, Kim DH, Cho J, Moon SH (2002) Characterization of anion exchange membranes with natural organic matter (NOM) during electrodialysis. Desalination $151: 43-52$. 
[35] Kim DH, Moon SH, Cho J (2002) Investigation of the adsorption and transport of natural organic matter (NOM) in ion-exchange membranes. Desalination 151:1120.

[36] Ma H, Allen HE, Yin Y (2001) Characterization of isolated fractions of dissolved organic matter from natural waters and wastewater effluent Wat. Res. 35(4):985996.

[37] Robertson PM, Gnehm W (1983) High efficiency hypochlorite generation. J. Appl. Electrochem. 13:307-315.

[38] Wulff J, Cornell A (2007) Cathodic current efficiency in the chlorate process. J. Appl. Electrochem. 37:181-186 


\section{Figure captions}

Fig. 1. Schematic representation of the proposed electrodialysis-electrochlorination process.

Fig. 2. a) Experimental set-up. b) Detail of the electrochemical cell.

Fig. 3. a) Evolution of the conductivity and the current efficiency the diluate tank with the applied electric charge during the ED-ECh process. b) Evolution of electrogenerated hypochlorite in the electrode rinsing solution with the applied electric charge. Electrode rinsing solution: $1500 \mathrm{mg} \mathrm{dm}^{-3} \mathrm{NaCl} ; \Delta \mathrm{V}: 7 \mathrm{~V} ; \mathrm{T}: 25^{\circ} \mathrm{C} ; 3$ pairs of cells; $3 \mathrm{C}$ scheme.

Fig. 4. Evolution of TOC in the diluate tank with the applied electric charge during the ED-ECh process. Electrode rinsing solution: $1500 \mathrm{mg} \mathrm{dm}^{-3} \mathrm{NaCl} ; \Delta \mathrm{V}: 7 \mathrm{~V} ; \mathrm{T}: 25^{\circ} \mathrm{C} ; 3$ pairs of cells; 3C scheme.

Fig. 5. a) Evolution of the conductivity and the current efficiency the diluate tank with the applied electric charge during the ED-ECh process. b) Evolution of electrogenerated hypochlorite in the electrode rinsing solution with the applied electric charge. Electrode rinsing solution: $1500 \mathrm{mg} \mathrm{dm}^{-3} \mathrm{NaCl} ; \Delta \mathrm{V}: 7 \mathrm{~V} ; \mathrm{T}: 25^{\circ} \mathrm{C} ; 3$ pairs of cells; $4 \mathrm{C}$ scheme.

Fig. 6. a) Evolution of the conductivity and the current efficiency the diluate tank with the applied electric charge during the ED-ECh process. b) Evolution of electrogenerated hypochlorite in the electrode rinsing solution with the applied electric charge. Electrode rinsing solution: $1500 \mathrm{mg} \mathrm{dm}^{-3} \mathrm{NaCl} ; \Delta \mathrm{V}: 7 \mathrm{~V} ; \mathrm{T}: 25^{\circ} \mathrm{C} ; 6$ pairs of cells; $4 \mathrm{C}$ scheme.

Fig. 7. Evolution of the hypochlorite concentration in the anolyte with the applied electric charge during the ED-ECh process. Anode and cathode rinsing solution: $\mathbf{a} 500 \mathrm{mg} \mathrm{dm}^{-3}$, $\uparrow 750 \mathrm{mg} \mathrm{dm}^{-3}, \bullet 1000 \mathrm{mg} \mathrm{dm}^{-3}, \Delta 2000 \mathrm{mg} \mathrm{dm}^{-3} ; \Delta \mathrm{V}: 7 \mathrm{~V} ; \mathrm{T}: 25^{\circ} \mathrm{C}$; 3 pairs of cells; $4 \mathrm{C}$ scheme.

Fig. 8. a) Variation of the concentration of E. Coli with the added hypochlorite during the chemical disinfection process. b) Evolution of the conductivity with the added hypochlorite. Catholyte/anolyte: $750 \mathrm{mg} \mathrm{dm}^{-3} \mathrm{NaCl} ; \Delta \mathrm{V}: 7 \mathrm{~V} ; \mathrm{T}: 25^{\circ} \mathrm{C} ; 3$ pairs of cells; $4 \mathrm{C}$ scheme. 


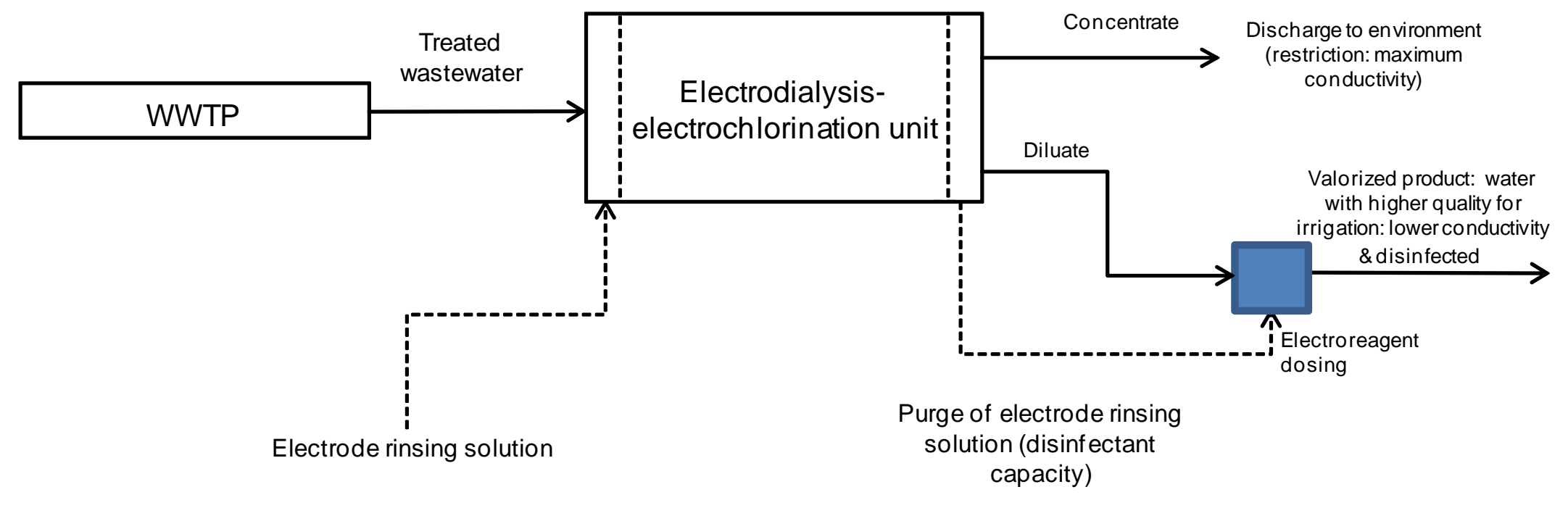

Fig. 1 


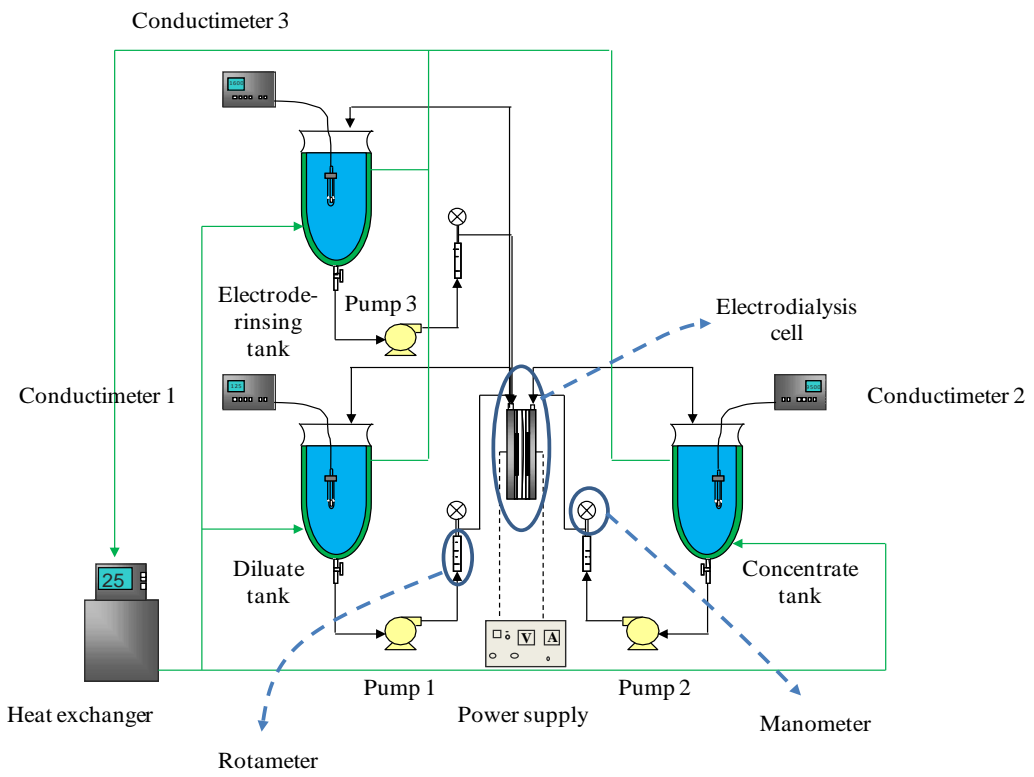

Fig. 2.a

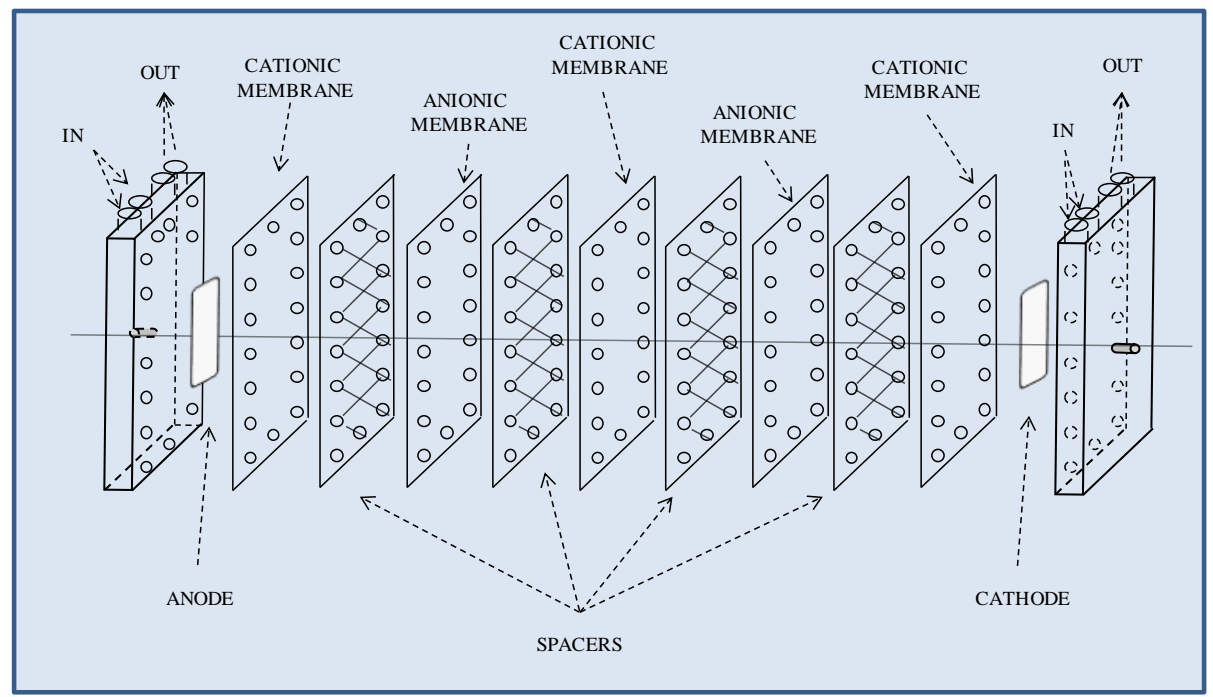

Fig. 2.b 
14

15

16

17

19

20

21

22

23

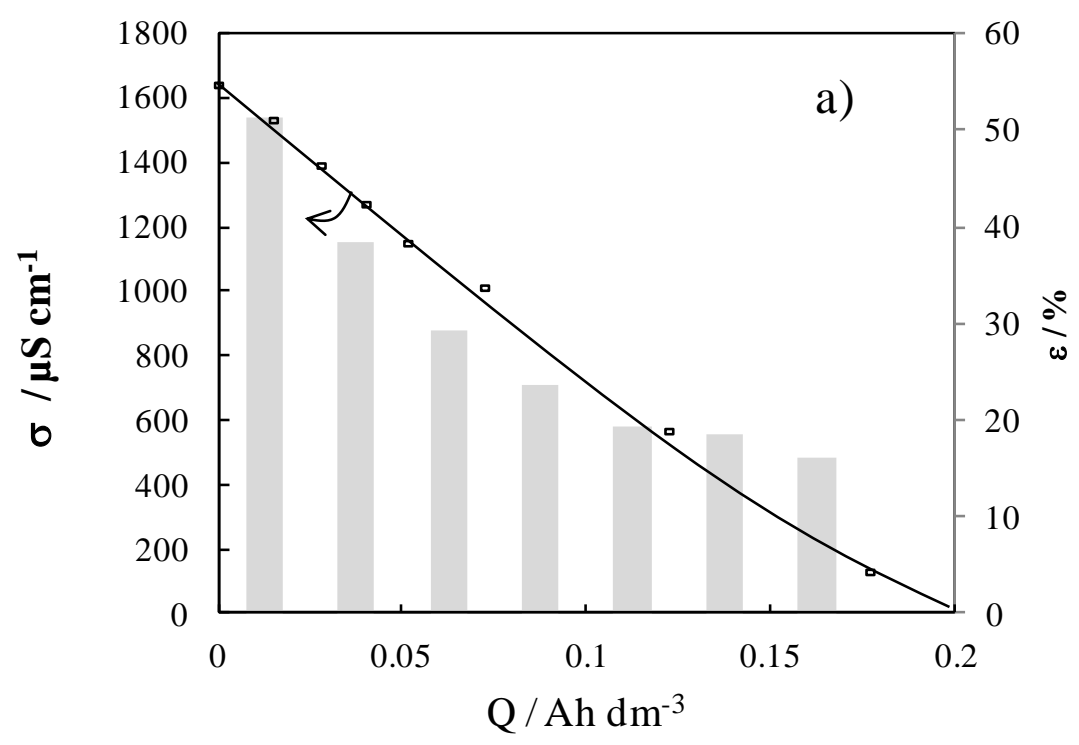

Fig. 3.a

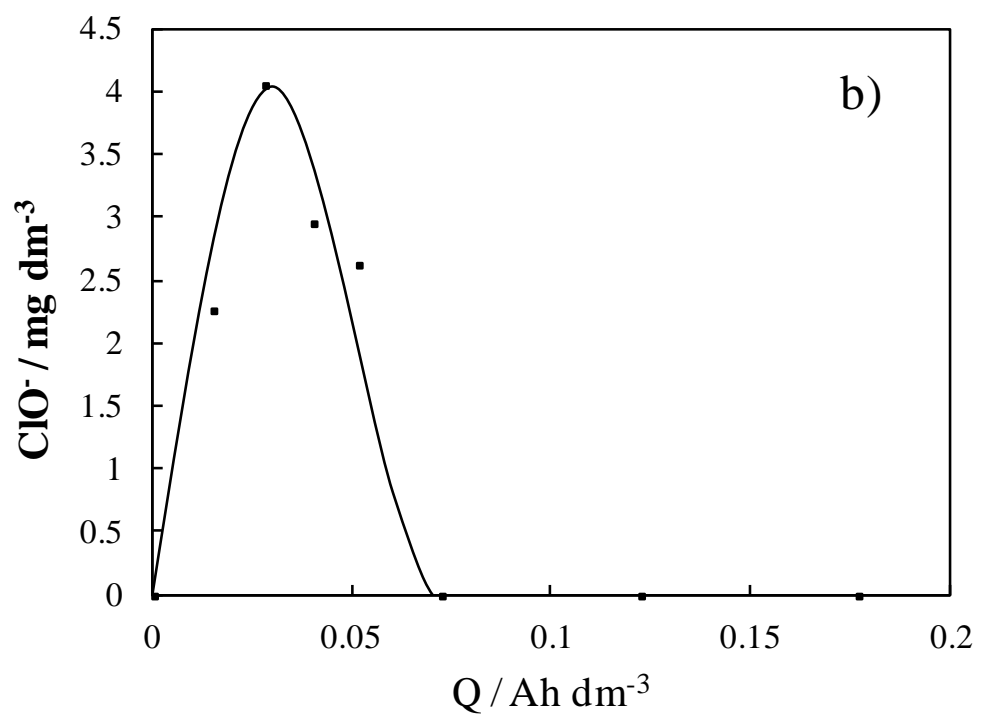

Fig. 3.b 


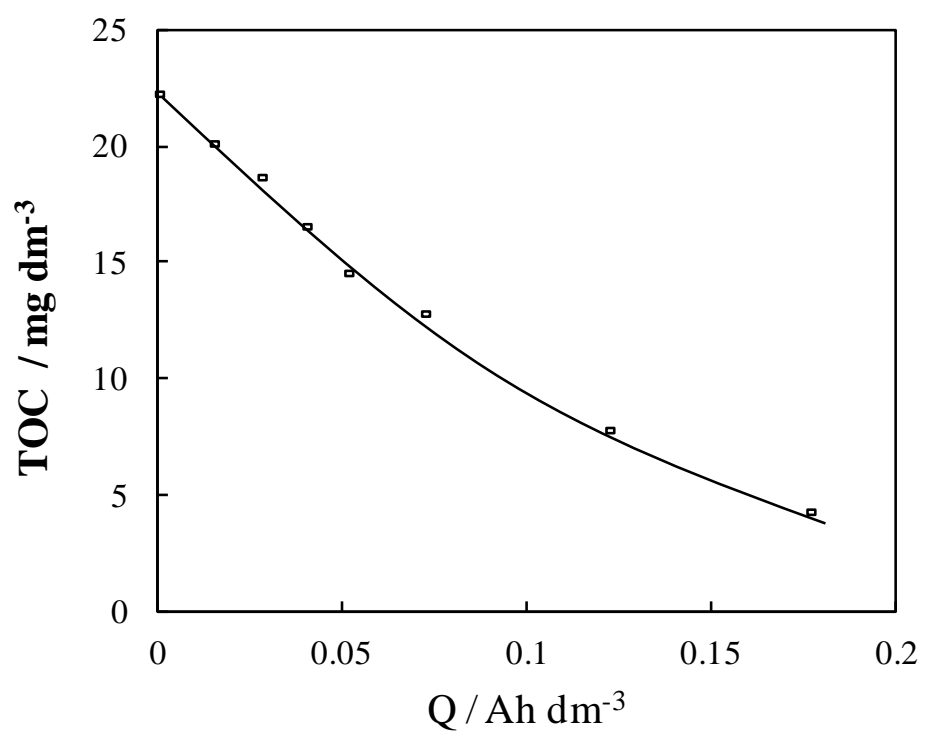

24

26

27

28

29

30

31

32

33

34

35

36

37

38

39

40

41

42

43

Fig. 4 
44

45

46

47

48

49

50

51

52

53

54

55

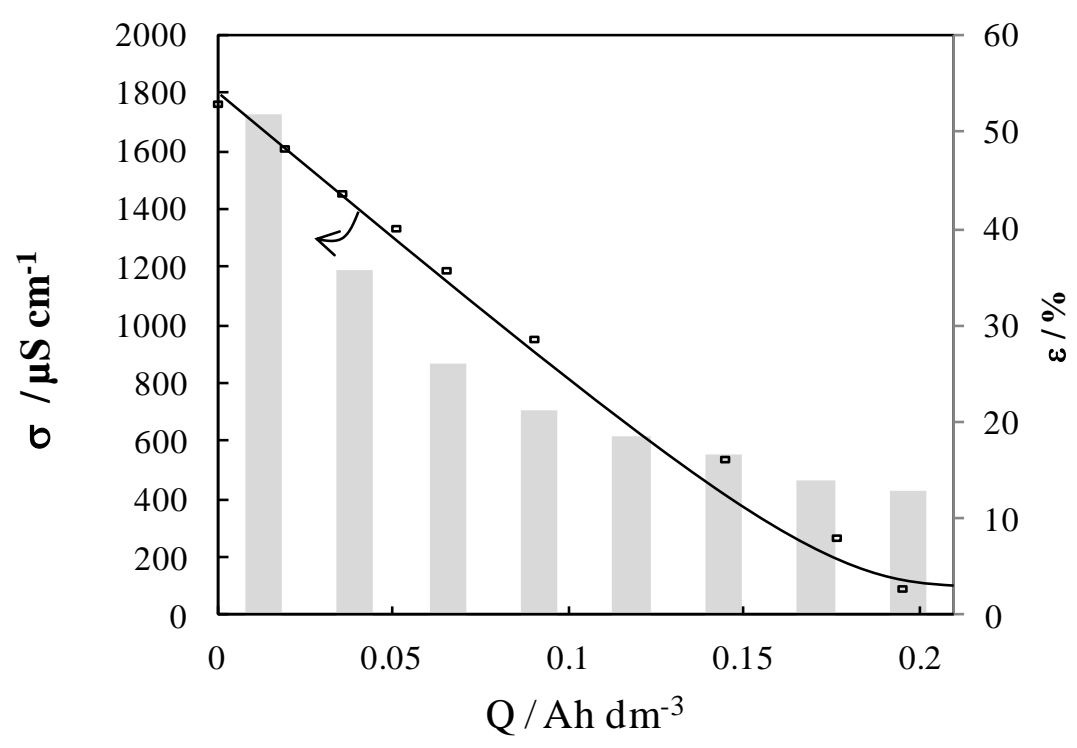

Fig. 5.a

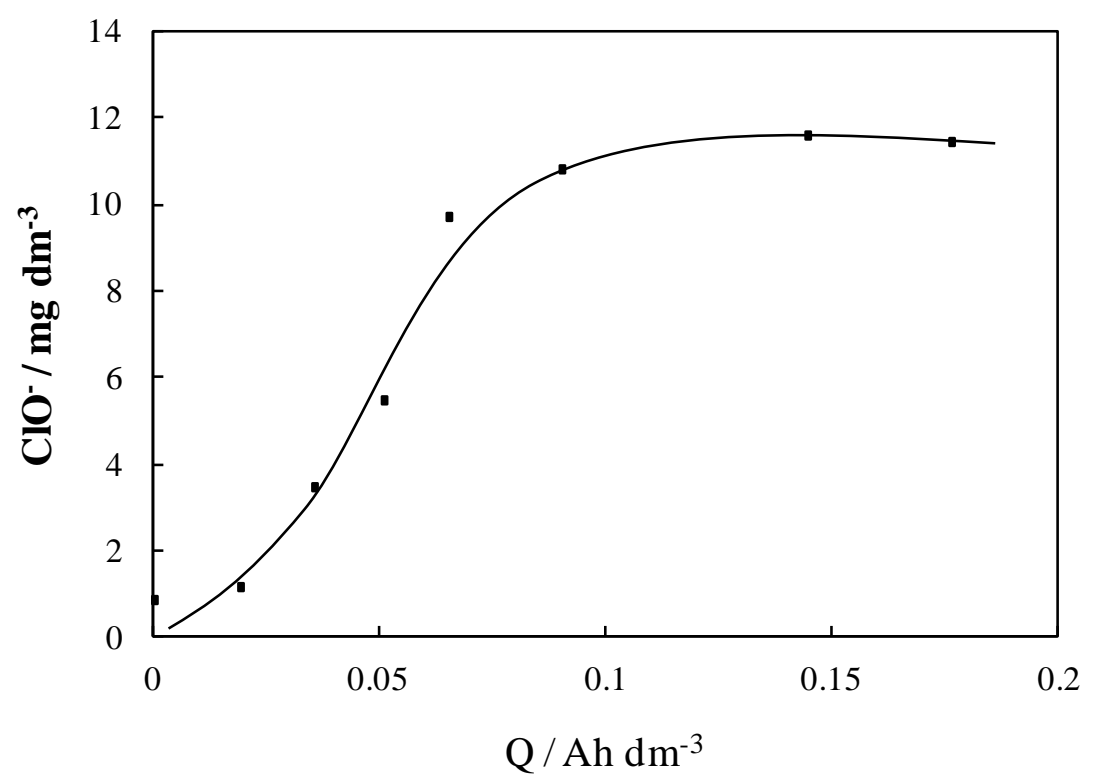

Fig. 5.b 
56
57

58

59

60

61

62

63

64

65

66

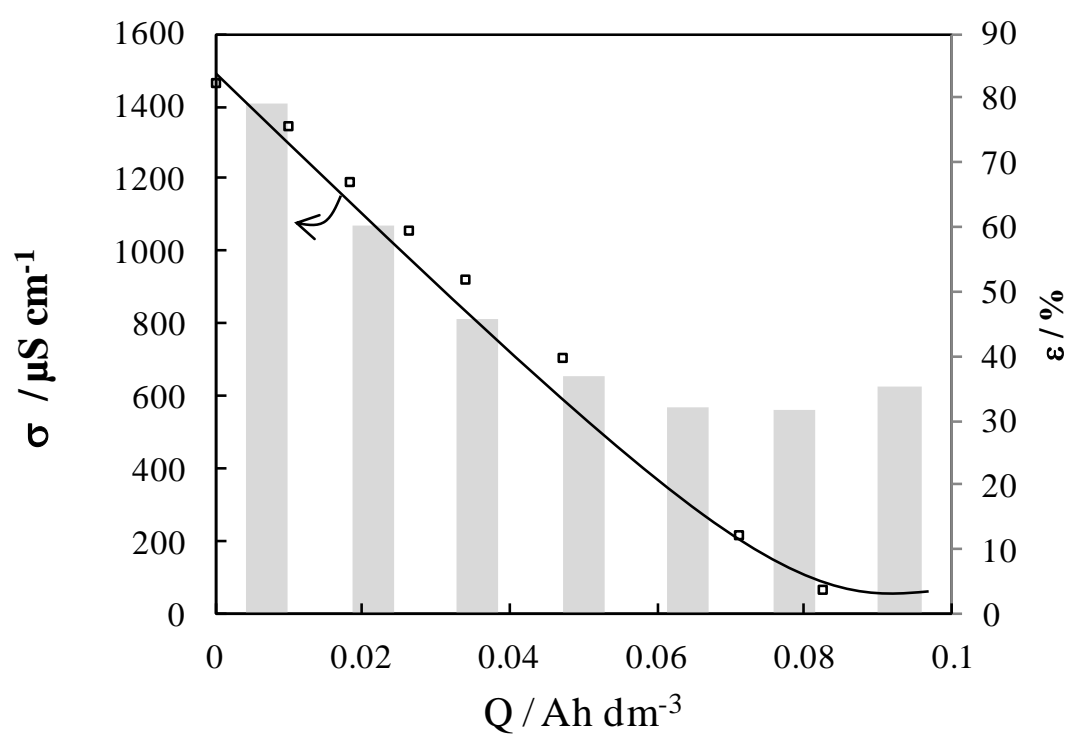

Fig. 6.a

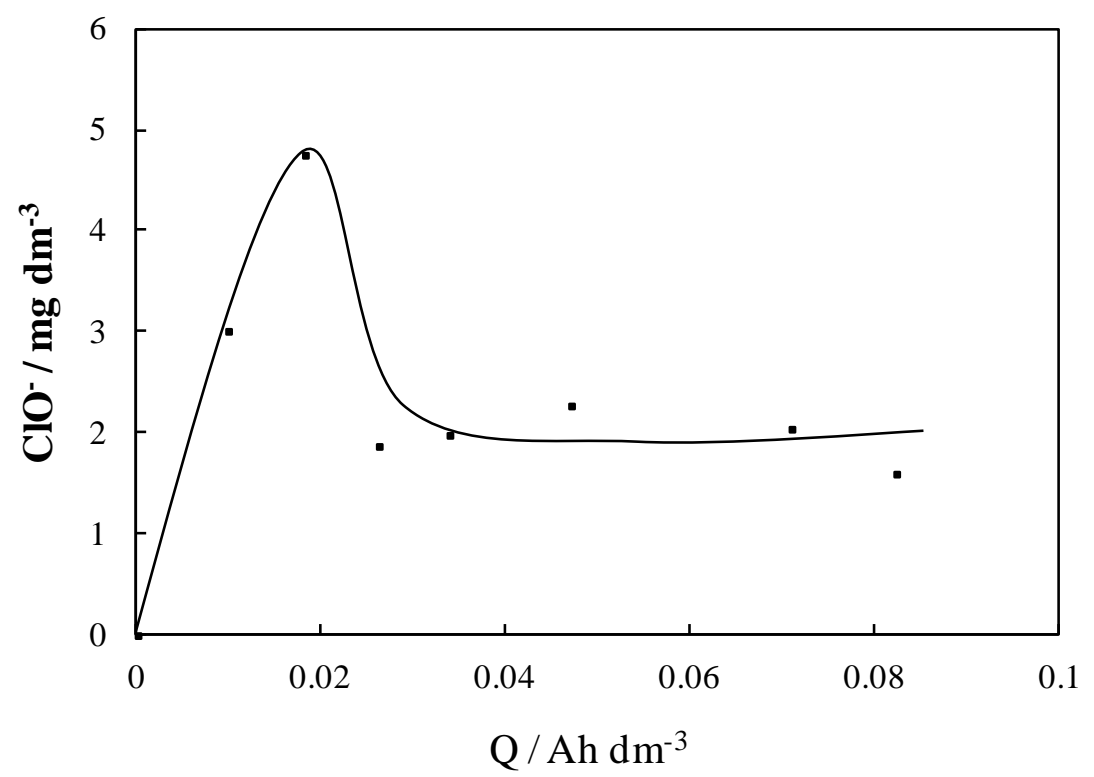

Fig. 6.b 


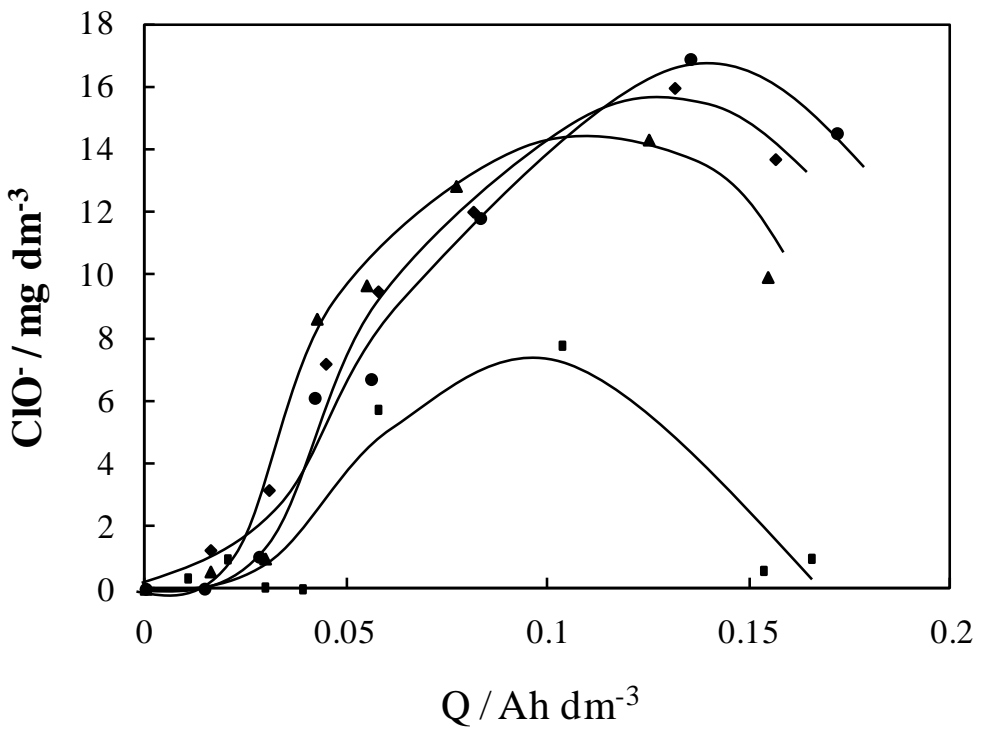

67

68

69

70

71

72

73

74

75

76

77

78

79

80

81

82

83

84

85

Fig. 7

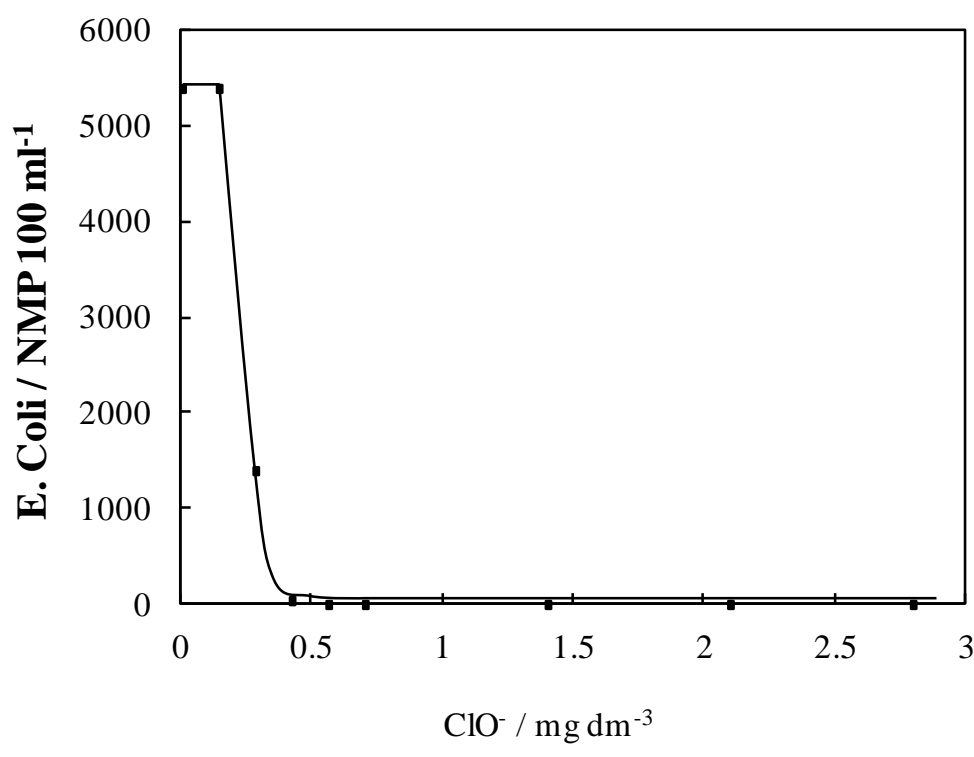


87

88

89

90

91

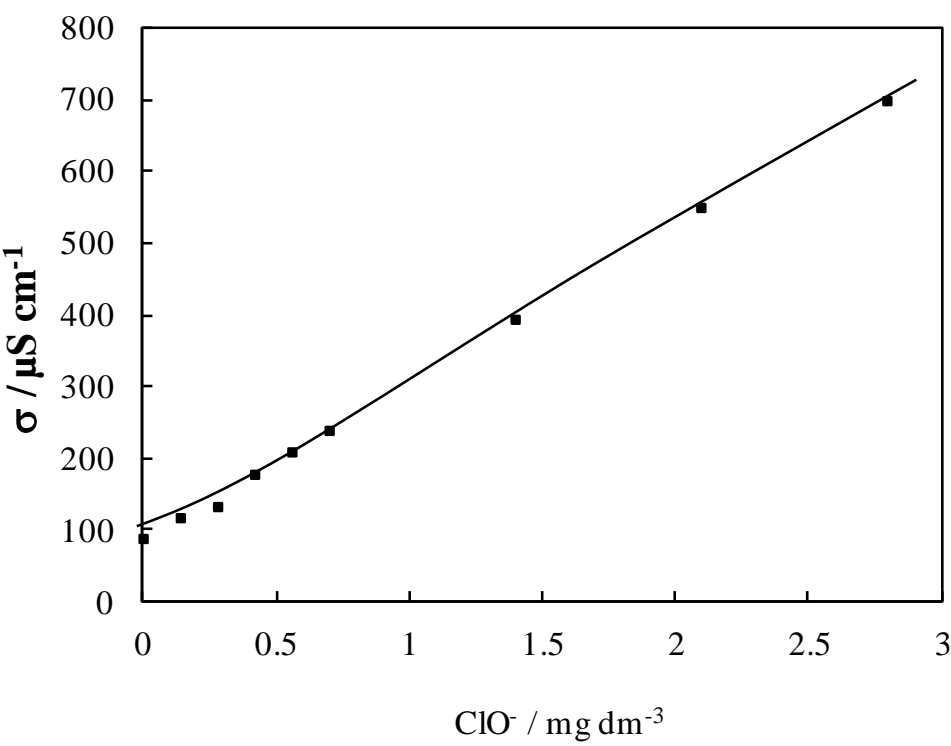

92

94

95

96

97

98

99

100

101

102

103

104

105

106

107

108
Fig. 8.a

Fig. 8.b 
110 Table 1. Representative average composition of target wastewater.

\begin{tabular}{cc}
\hline Parameter & Concentration \\
\hline $\mathrm{Cl}^{-}$ & $162.99 \mathrm{mg} \mathrm{dm}^{-3}$ \\
\hline $\mathrm{NO}_{3}^{-}$ & $1.58 \mathrm{mg} \mathrm{dm}^{-3}$ \\
\hline $\mathrm{NH}_{4}^{+}$ & $45.42 \mathrm{mg} \mathrm{dm}^{-3}$ \\
\hline $\mathrm{SO}_{4}{ }^{2-}$ & $255.27 \mathrm{mg} \mathrm{dm}^{-3}$ \\
\hline $\mathrm{Na}^{+}$ & $141.33 \mathrm{mg} \mathrm{dm}^{-3}$ \\
\hline E. Coli & $9100 \mathrm{CFU} / 100 \mathrm{ml}$ \\
\hline
\end{tabular}

111

112

113

114

115

116

117

118

119

120

121 